\title{
Haematological features of angioimmunoblastic lymphadenopathy with dysproteinaemia
}

\author{
R. L. BREARley, J. CHAPMAN, M. H. CULlen, M. A. HORTON, \\ A. G. STANSFELD, AND A. H. WATERS
}

From the Departments of Haematology, Histopathology, and Medical Oncology, St Bartholomew's Hospital and Medical College, London EC1A 7BE, UK

SUMMARY A study of seven patients with AILD has confirmed previously reported cytological and immunological changes in the peripheral blood. In themselves these changes should not be considered as specific. Histological examination of the bone marrow may show more characteristic lesions which involve haemopoietic, lymphoid, and stromal cells. Three patients had bone marrow features similar to myelofibrosis, which are considered to be diagnostic of AILD.

Angioimmunoblastic lymphadenopathy with dysproteinaemia (AILD) (Frizzera et al., 1974; 1975) and immunoblastic lymphadenopathy (IBL) (Lukes and Tindle, 1975) have been independently described and are possibly identical clinicopathological syndromes which are distinct from Hodgkin's disease and non-Hodgkin's lymphoma. Both AILD and IBL may prove rapidly fatal and yet lack conventional histological criteria of malignancy. Pathological diagnosis is based on a triad of lymph node changes, namely, obliteration of nodal architecture by a pleomorphic lymphocyte, plasma cell and immunoblast proliferation, prominent arbourising vasculature, and intercellular deposits of eosinophilic, periodic acid-Schiff (PAS) positive material.

Clinically, the syndromes usually present as a systemic disease, with generalised lymphadenopathy, hepatosplenomegaly, a maculopapular skin rash, and constitutional symptoms. Typical cases exhibit a polyclonal increase in immunoglobulins, and in two-thirds the Coombs' (anti-globulin) test is positive (Frizzera et al., 1975; Lukes and Tindle, 1975; Flandrin, 1976; Neiman et al., 1978; Pangalis et al., 1978). Rappaport and co-workers have recently reported a higher incidence of blood and marrow involvement with AILD than they initially described, and they suggest that marrow changes, in particular, are as diagnostic of AILD as lymph node histology (Pangalis et al., 1978). We report here our experience of AILD/IBL with particular reference to the haematological features.

Received for publication 23 August 1978

\section{Material and methods}

Seven patients were identified by one of us (AGS) on the basis of the pretreatment histology of lymph nodes from six patients and a skin biopsy in one. Peripheral blood and bone marrow aspirates were available in all patients and trephine biopsies in six. The Coombs' test was performed using monospecific antisera to $\operatorname{IgG}, \operatorname{IgM}, \operatorname{IgA}$, and complement $(2 \mathrm{~d} / \mathrm{C} 3 \mathrm{~d})$ in six patients and with a broad-spectrum reagent in one. Red cell eluates, prepared by the method of Rubin (1963), and sera were screened for antibody specificity against a typed panel of red cells using low temperature saline, albumin, papain, and antiglobulin techniques.

\section{Results}

CLINICAL FEATURES

Presenting symptoms and clinical findings are summarised in Table 1. All patients had constitutional symptoms, and four had skin rashes unrelated to drug exposure. Generalised lymphadenopathy was found in all patients and splenomegaly or hepatomegaly in six. The patients were treated with steroids and cytotoxic drugs, and all have died. Survival from the onset of symptoms, terminal events, and necropsy findings are shown in Table 1. The major terminal illness in five patients was pneumonia or septicaemia. There was necropsy evidence of cytomegalovirus (CMV) and Pneumocystis carinii infection in two patients. Although generalised AILD/IBL lesions were found at 
necropsy in four patients, the process appeared to be 'burnt out' in two patients, being characterised by lesions showing lymphocyte depletion, hyalinisation, and fibrosis. Transformation to a malignant immunoblastic lymphoma was observed in two patients.

\section{PERIPHERAL BLOOD}

The haematological findings in the peripheral blood are shown in Table 2. The most striking changes were found in the white cell series. The total count ranged from 6.2 to $32.7 \times 10^{9} / 1$. Differential counts indicated neutrophilia in two patients, eosinophilia in four, and lymphocytopenia $\left(<1.5 \times 10^{9} / 1\right)$ in five patients. Lymphoplasmacytoid or 'atypical mononuclear' cells were present in the blood of all patients. Five patients had a normochromic, normocytic anaemia, but two (cases 2 and 7) had evidence of haemolysis with spherocytosis, reticulocytosis, and raised plasma bilirubin ( $>40 \mu \mathrm{mol} / \mathrm{l})$, although only case 2 had a positive Coombs' test. The platelet count was $>100 \times 10^{9} / 1$ in all cases.

\section{SEROLOGY}

Five patients exhibited a diffuse hypergamma- globulinaemia, and five, a positive Coombs' test (Table 2). Tests with monospecific antisera showed red cell coating with IgG and complement in three patients, and IgG alone in one. Warm-type autoantibodies were detected in the serum of patients with a positive direct Coombs' test, and similar autoantibodies were found in the red cell eluates. Specificity for these autoantibodies could not be established, but allo-anti-E was detected in the sera of two patients and allo-anti-E plus Kell in another.

\section{BONE MARROW}

Results of bone marrow aspirates and trephine biopsies are shown in Table 3. The cellularity of aspirated marrow fragments was normal in one patient but moderately to markedly increased in the others. Erythropoiesis was normoblastic, and precursors were present in normal numbers in three patients, moderately increased in two, but decreased ( $<10 \%$, nucleated cell count) in two. Eosinophils were increased $(>10 \%)$ in four patients. Plasma cells and lymphoplasmacytoid cells similar in morphology to those seen in peripheral blood and lymph node imprints were present in all patients.

Unilateral bone marrow trephine biopsies were

Table 1 Clinical features at presentation and death

\begin{tabular}{|c|c|c|c|c|c|c|c|}
\hline Case & Age & $\operatorname{Sex}$ & $\begin{array}{c}\text { Presenting symptoms } \\
.\end{array}$ & Physical findings & $\begin{array}{l}\text { Survival } \\
\text { (months) }\end{array}$ & Terminal events & Necropsy findings \\
\hline 1 & 62 & $\mathbf{M}$ & $\begin{array}{l}\text { Anorexia, pruritus, acute } \\
\text { abdominal pain }\end{array}$ & $\begin{array}{l}\text { Lymphadenopathy, } \\
\text { spontaneous splenic } \\
\text { rupture }\end{array}$ & 6 & $\begin{array}{l}\text { Gastrointestinal } \\
\text { haemorrhage }\end{array}$ & $\begin{array}{l}\text { Generalised, active } \\
\text { AILD/IBL }\end{array}$ \\
\hline 2 & 69 & $\mathbf{M}$ & $\begin{array}{l}\text { Anorexia, weight loss, } \\
\text { enlarging lymph nodes }\end{array}$ & $\begin{array}{l}\text { Lymphadenopathy, } \\
\text { splenomegaly }\end{array}$ & 6 & Septicaemia & $\begin{array}{l}\text { CMV, Pneumocystis } \\
\text { carinii pneumonia, } \\
\text { 'burnt-out' AILD/IBL }\end{array}$ \\
\hline 3 & 63 & $\mathbf{M}$ & $\begin{array}{l}\text { Anorexia, weight loss, } \\
\text { skin rash }\end{array}$ & $\begin{array}{l}\text { Lymphadenopathy, } \\
\text { splenomegaly, Raynaud's } \\
\text { phenomenon }\end{array}$ & 14 & $\begin{array}{l}\text { Unresponsive immuno- } \\
\text { blastic lymphoma }\end{array}$ & 一 \\
\hline 4 & 50 & $\mathbf{M}$ & $\begin{array}{l}\text { Skin rash, night sweats, } \\
\text { dyspnoea }\end{array}$ & Lymphadenopathy & 19 & Septicaemia & $\begin{array}{l}\text { Peritonitis, immunoblastic } \\
\text { lymphoma }\end{array}$ \\
\hline 5 & 62 & $\mathbf{F}$ & $\begin{array}{l}\text { Arthralgia, night sweats, } \\
\text { weight loss, skin rash }\end{array}$ & $\begin{array}{l}\text { Lymphadenopathy, } \\
\text { hepatosplenomegaly }\end{array}$ & 23 & Pneumonia & $\begin{array}{l}\text { CMV, Pneumocystis } \\
\text { carinii pneumonia, } \\
\text { 'burnt-out' AILD/IBL }\end{array}$ \\
\hline 6 & 75 & $\mathbf{F}$ & Malaise, dyspnoea & $\begin{array}{l}\text { Lymphadenopathy, } \\
\text { hepatosplenomegaly }\end{array}$ & 9 & Pneumonia & 一 \\
\hline 7 & 53 & $\mathbf{F}$ & $\begin{array}{l}\text { Malaise, night sweats, } \\
\text { skin rash }\end{array}$ & $\begin{array}{l}\text { Lymphadenopathy, } \\
\text { hepatomegaly }\end{array}$ & 15 & Septicaemia, renal failure & $\begin{array}{l}\text { Generalised, active } \\
\text { AILD/IBL, tubular } \\
\text { necrosis }\end{array}$ \\
\hline
\end{tabular}

Table 2 Peripheral blood findings at presentation

\begin{tabular}{|c|c|c|c|c|c|c|c|c|c|}
\hline Case & $\begin{array}{l}H b \\
(g / d l)\end{array}$ & $\begin{array}{l}\text { Retics } \\
\%\end{array}$ & $\begin{array}{l}\text { Total } \\
W B C^{*}\end{array}$ & Neutrophils* & Eosinophils* & Lymphocytes* & Lymphoplasmacytoid* & Coombs' test & Hypergammaglobulinaemia \\
\hline $\begin{array}{l}1 \\
2 \\
3 \\
4 \\
5 \\
6 \\
7\end{array}$ & $\begin{array}{r}12.4 \\
8.2 \\
11.5 \\
7.8 \\
8.8 \\
9.0 \\
11.8\end{array}$ & $\begin{array}{c}2.4 \\
11.6 \\
2.8 \\
1.4 \\
0.2 \\
1.8 \\
5.6\end{array}$ & $\begin{array}{r}32 \cdot 7 \\
7 \cdot 4 \\
13 \cdot 2 \\
15 \cdot 7 \\
6 \cdot 3 \\
6 \cdot 2 \\
19 \cdot 1\end{array}$ & $\begin{array}{r}29.4 \\
5.3 \\
9.4 \\
5 \cdot 0 \\
5 \cdot 4 \\
5 \cdot 2 \\
13.4\end{array}$ & $\begin{array}{l}0.3 \\
0.5 \\
1 \cdot 2 \\
8 \cdot 2 \\
0.3 \\
0 \cdot 1 \\
1 \cdot 0\end{array}$ & $\begin{array}{l}1.6 \\
1.0 \\
0.9 \\
1.4 \\
0.3 \\
0.5 \\
1.5\end{array}$ & $\begin{array}{l}0.3 \\
0.4 \\
0.3 \\
0.6 \\
0.1 \\
0.3 \\
2.5\end{array}$ & $\begin{array}{l}+ \\
+ \\
+ \\
+ \\
+ \\
-\end{array}$ & $\begin{array}{l}+ \\
+ \\
+ \\
+ \\
+ \\
+ \\
+\end{array}$ \\
\hline
\end{tabular}


Table 3 Bone marrow findings at presentation

\begin{tabular}{lllclc}
\hline $\begin{array}{llll}\text { Case } \\
\text { aspirated fragments }\end{array}$ & $\begin{array}{l}\text { Cellularity of } \\
\text { asythroid precursors* }\end{array}$ & Eosinophils* & Lymphoplasmacytoid and plasma cells* & Trephine biopsy histology \\
\hline 1 & Increased & 16 & 8 & 33 & Normal \\
2 & Normal & 50 & 3 & 21 & Paratrabecular infiltrates \\
3 & Increased & 28 & 19 & 19 & Diffuse fibrosis \\
4 & Increased & 6 & 42 & 20 & Diffuse fibrosis \\
5 & Increased & $0 \cdot 5$ & 18 & 19 & Diffuse fibrosis \\
6 & Increased & 20 & 3 & 16 & Normal \\
7 & Increased & 22 & 11 & 34 & Not done \\
\hline
\end{tabular}

$* \%$ Nucleated cell count

available in four patients and bilateral iliac crest biopsies in two. Overall marrow architecture was within normal limits in two patients but abnormal in four. The marrow of three patients was of increased cellularity (in bilateral biopsies in two cases) due to hyperplasia of haemopoietic elements, especially eosinophils, and a diffuse infiltrate of lymphoplasmacytoid and plasma cells. Interspersed throughout the marrow were spindle-shaped cells resembling fibroblasts and, occasionally, endothelial cells. When sections were stained for reticulin, these changes were shown to be associated with a considerable increase in small and medium-sized fibres, giving the appearances of myelofibrosis (Figure). The marrow trephine biopsy of the remaining patient showed small areas of paratrabecular fibrosis and cellular depletion and a single, indistinct, paratrabecular focus of mononuclear cells and eosinophils.

\section{Discussion}

The patients in this study showed most of the clinical features previously described in AILD/IBL (Cullen et al., 1979). These features are also shared by patients with drug hypersensitivity reactions, systemic lupus erythematosus (SLE), and other collagen diseases (Frizzera et al., 1975; Lukes and Tindle, 1975; Budman and Steinberg, 1977). Even the histo-

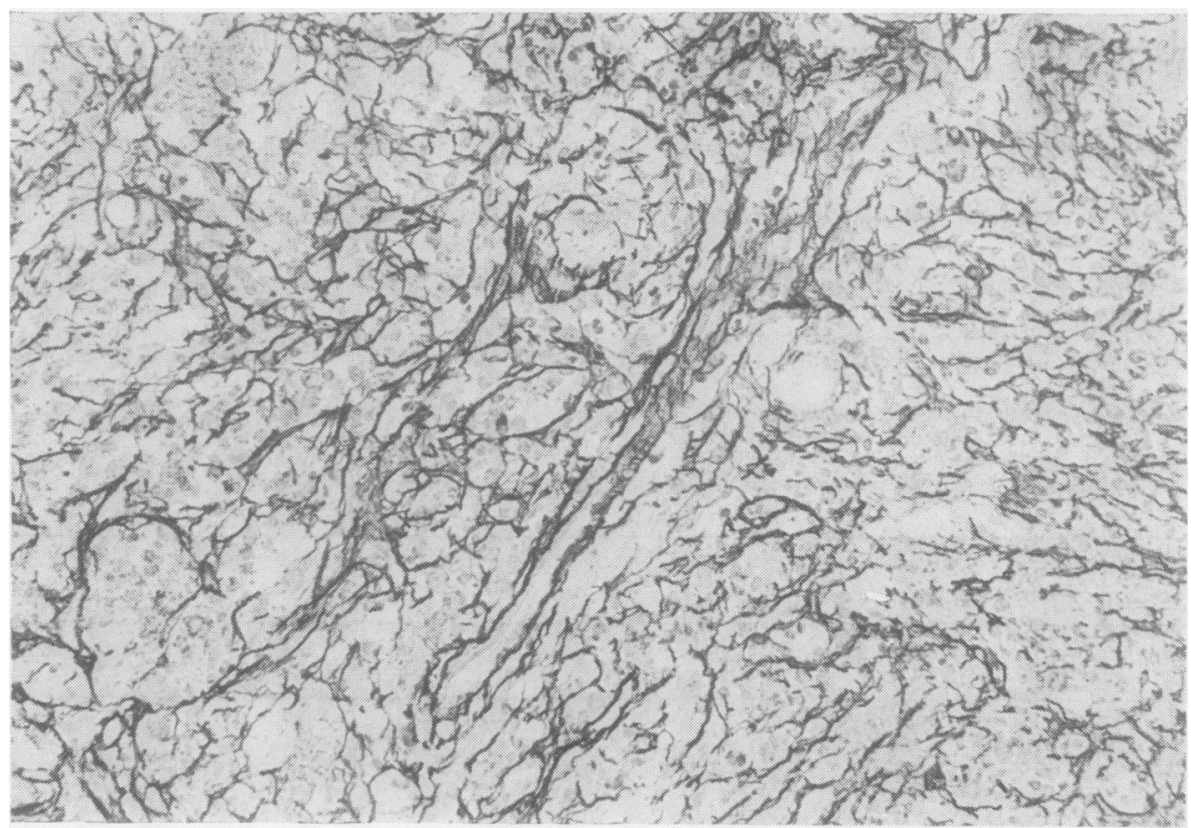

Figure Bone marrow biopsy showing diffuse myelofibrosis with small and medium-sized reticulin fibres. Reticulin $\times 400$. 
logical changes may be found singly or in combination in other conditions. A pleomorphic, immunoblastic reaction in lymph nodes may be a feature of drug hypersensitivity (Saltzstein and Ackerman, 1959) and post-vaccinial lymphadenitis (Hartsock, 1968). Prominent vascular changes are found in graft versus host reactions (Graham, 1974) and malignant lymphomas of centrocytic type (Lennert et al., 1975). Interstitial, PAS-positive material has been reported in lymph nodes involved in delayed hypersensitivity (Willoughby and Spector, 1964) and nodular (follicular) lymphomas (Rosas-Uribe et al., 1973).

Anaemia is present in over $80 \%$ of patients with AILD/IBL and a positive Coombs' test in approximately 50\% (Neiman et al., 1978; Pangalis et al., 1978; Cullen et al., 1979). All the patients in the present study were anaemic; five had a positive Coombs' test, but in only one patient was there convincing evidence of immune haemolysis. The serological findings did not differentiate AILD/IBL from other disorders associated with a positive Coombs' test (Dacie, 1962; Budman and Steinberg, 1977), although the presence of allo-anti-E in the sera of three patients is unusual.

Changes in peripheral blood neutrophil, eosinophil, and lymphocyte counts are common in AILD/ IBL but are known to occur in drug hypersensitivity and inflammatory, collagen-vascular, and Hodgkin's disease. Atypical mononuclear cells, lymphoplasmacytoid cells, and 'immunocytes' in the blood were not mentioned in original descriptions of IBL (Lukes and Tindle, 1975) and were reported in only two of 24 cases of AILD (Frizzera et al., 1975) but have now been described in frequencies of between $32 \%$ (Pangalis et al., 1978) and $92 \%$ of cases (Flandrin, 1976). The morphology of these cells is not unique but their presence in the blood, together with the other changes, should alert haematologists to the possibility of AILD/IBL.

Bone marrow aspirates reflect, in general, changes that would be anticipated from peripheral blood findings. There may, however, be a discordance between a positive Coombs' test, reticulocytosis, or erythroid hyperplasia (Flandrin, 1976; Pangalis et al., 1978), indicating multiple causes for any anaemia. Two patients in the present series had a positive Coombs' test and erythroblastopenia. In one patient erythropoiesis recovered after antibiotic therapy for Gram-negative septicaemia. It has been implied that lymphoplasmacytoid cells or immunocytes in the marrow of patients with AILD indicates extranodal extension of the disease (Pangalis et al., 1978), yet Turesson (1976) has estimated that approximately $2.3 \times 10^{9}$ immunoglobulin containing cells are present in normal marrow, which is the major organ of IgG synthesis in man (McMillan et al., 1972). Rappaport and coworkers have suggested that sections of aspirated marrow fragments and trephine biopsies may show lesions that are as diagnostic of AILD as lymph node histology (Pangalis et al., 1978). These changes are focal, often paratrabecular areas of fibroblast and endothelial cell proliferation associated with haemopoietic depletion. The foci may coalesce, resulting in extensive marrow hypoplasia and fibrosis. The present study confirms that paratrabecular fibrosis and cellular depletion may be features of AILD and are easily differentiated from the distinctive paratrabecular infiltrates of malignant lymphomas of centroblastic-centrocytic histology (Brearley and Stansfeld, 1978). There is a remote possibility that, with sections examined in isolation from the relevant clinical and laboratory data, the lesions could be confused with the early marrow changes of Hodgkin's disease, systemic mastocytosis, or osteitis fibrosa cystica. Three patients had marrow changes that, in our experience, are unique to the AILD/IBL syndrome: obliteration of the normal architecture by haemopoietic proliferation, especially eosinophils, a diffuse infiltrate of lymphoplasmacytoid and plasma cells, and a marked increase in spindle-shaped cells, resulting in an appearance resembling myelofibrosis when sections are stained for reticulin. A single case, with similar marrow changes, has been described by Scully et al. (1978) and was included in the original IBL series of Lukes and Tindle (1975).

The pathogenesis of the marrow lesions, especially the stromal changes, is unknown. The AILD/IBL syndrome may resolve spontaneously or undergo transformation to an immunoblastic, malignant lymphoma (Lukes and Tindle, 1975; Nathwani et al., 1978), but the presence of marrow involvement does not appear to have an adverse effect on prognosis (Pangalis et al., 1978). In the present study it is probably fortuitous that the patients with extensive marrow fibrosis survived longer than those with absent or only minimal changes.

\section{References}

Brearley, R. L., and Stansfeld, A. G. (1978). Recognition of minimal bone-marrow infiltration by lymphoid malignancies. XVII Congress of the International Society of Haematology, Paris.

Budman, D. R., and Steinberg, A. D. (1977). Hematologic aspects of systemic lupus erythematosus-current concepts. Annals of Internal Medicine, 86, 220-229.

Cullen, M. H., Stansfeld, A. G., Oliver, R. T. D., Lister, T. A., and Malpas, J. S. (1979). Angio-immunoblastic lymphadenopathy-report of ten cases and review of the literature. Quarterly Journal of Medicine, (In press). 
Dacie, J. V. (1962). The Haemolytic Anaemias-Congenital and Acquired, Part II, The Auto-immune Haemolytic Anaemias, 2nd edition. Churchill, London.

Flandrin, G. (1976). Adénopathies angio-immunoblastiques avec anémie auto-immune et hyperimmunoglobulinémie polyclonale. Nouvelle Presse Médicale, 5, 1521-1524.

Frizzera, G., Moran, E. M., and Rappaport, H. (1974). Angio-immunoblastic lymphadenopathy with dysproteinaemia. Lancet, 1, 1070-1073.

Frizzera, G., Moran, E. M., and Rappaport, H. (1975). Angio-immunoblastic lymphadenopathy: diagnosis and clinical course. American Journal of Mèdicine, 59, 813-818.

Graham, R. C., Jr. (1974). Pathogenesis of vascular proliferation in angio-immunoblastic lymphadenopathy with dysproteinaemia (Letter). Lancet, 2, 666.

Hartsock, R. J. (1968). Post vaccinial lymphadenitis. Hyperplasia of lymphoid tissue that simulates malignant lymphomas. Cancer, 21, 632-649.

Lennert, K., Stein, H., and Kaiserling, E. (1975). Cytological and functional criteria for the classification of malignant lymphomata. British Journal of Cancer, 31, Supplement 2, 29-43.

Lukes, R. J., and Tindle, B. H. (1975). Immunoblastic lymphadenopathy - a hyperimmune entity resembling Hodgkin's disease. New England Journal of Médicine, 292, 1-8.

McMillan, R., Longmire, R. L., Yelenosky, R., Lang, J. E., Heath, V., and Craddock, C. G. (1972). Immunoglobulin synthesis by human lymphoid tissues-normal bone marrow as a major site of $\mathrm{IgG}$ production. Journal of Immunology, 109, 1386-1394.

Nathwani, B. N., Rappaport, H., Moran, E. M., Pangalis,
G. A., and Kim, H. (1978). Malignant lymphoma arising in angio-immunoblastic lymphadenopathy. Cancer, 41, 578-606.

Neiman, R. S., Dervan, P., Haudenschild, C., and Jaffe, R. (1978). Angio-immunoblastic lymphadenopathy. An ultrastructural and immunologic study with review of the literature. Cancer, 41, 507-518.

Pangalis, G. A., Moran, E. M., and Rappaport, H. (1978). Blood and marrow findings in angioimmunoblastic lymphadenopathy. Blood, 51, 71-83.

Rosas-Uribe, A., Variakojis, D., and Rappaport, H. (1973). Proteinaceous precipitate in nodular (follicular) lymphomas. Cancer, 31, 534-542.

Rubin, H. (1963). Antibody elution from red blood cells. Journal of Clinical Pathology, 16, 70-73.

Saltzstein, S. L., and Ackerman, L. V. (1959). Lymphadenopathy induced by anticonvulsant drugs and mimicking clinically and pathologically malignant lymphomas. Cancer, 12, 164-182.

Scully, R. E., Galdabini, J. J., and McNeely, B. U. (1978). Case records of the Massachusetts General Hospital. New England Journal of Medicine, 298, 613-620.

Turesson, I. (1976). Distribution of immunoglobulincontaining cells in human bone marrow and lymphoid tissues. Acta Medica Scandinavica, 199, 293-304.

Willoughby, D. A., and Spector, W. G. (1964). The production of eosinophilic deposits resembling fibrinoid by injections of lymph-node extracts. Journal of Pathology and Bacteriology, 88, 557-562.

Requests for reprints to: Dr R. L. Brearley, Department of Haematology, St Bartholomew's Hospital, West Smithfield, London EC1A 7BE. 